\title{
Home Irrigation and Landscape Combinations for Water Conservation in Florida ${ }^{1}$
}

\author{
Melissa B. Haley, Michael D. Dukes, Grady L. Miller and Dorota Z. Haman²
}

\section{Introduction}

Irrigation has become commonplace for residential homeowners desiring high quality landscapes in Florida. Turfgrass is a key landscape component and normally the most commonly used single type of plant in the residential landscape. Although Florida has a humid climate where the precipitation rate, on average, is greater than the evapotranspiration rate, the winter and spring are normally dry. The dry winter/spring weather and sporadic large rain events in the summer coupled with low water holding capacity of the soil make irrigation necessary for the high quality landscapes desired by homeowners.

Residential water use comprises $61 \%$ of the public supply category. This public supply category is responsible for the largest single portion (43\%) of groundwater withdrawal in Florida. Between 1970 and 1995 there was a $135 \%$ increase in groundwater withdrawals. The current population of 16 million is projected to exceed 20 million by 2020 . The average residential irrigation cycle consumes several thousand gallons of water, and the average homeowner typically runs two cycles per week. Water conservation has become a major concern for Florida.

\section{Landscape Type and Irrigation Schedule Interaction}

Decreasing the amount of water consumed by a residential irrigation system without causing stress or reduced quality to the turfgrass and landscape, is possible. Based on a recent research project where 27 homes were monitored in Central Florida, residential lawns were categorized into one of three treatments based on lawn type and irrigation scheduling. Treatment one (T1) consisted of existing irrigation systems and typical landscape plantings (Figure 1), where the homeowner controlled the irrigation scheduling. Treatment two (T2) homes also consisted of existing irrigation systems and typical landscape plantings (Figure 1), but the irrigation scheduling was based on $60 \%$ replacement of historical evapotranspiration (ET). Treatment three (T3) consisted of an irrigation system designed according to specifications for optimal efficiency including a landscape design that minimized turfgrass and maximized the use of native drought-tolerant

1. This document is ABE 355, one of a series of the Agricultural and Biological Engineering Department, Florida Cooperative Extension Service, Institute of Food and Agricultural Sciences, University of Florida. Original publication date March 2005. Visit the EDIS Web Site at http://edis.ifas.ufl.edu.

2. Melissa B. Haley, Research Assistant, Department of Agricultural and Biological Engineering; Michael D. Dukes, Assistant Professor, Department of Agricultural and Biological Engineering; Grady L. Miller, Associate Professor, Department of Environmental Horticulture; and Dorota Z. Haman, Professor, Department of Agricultural and Biological Engineering; Florida Cooperative Extension Service, Institute of Food and Agricultural Sciences, University of Florida, Gainesville, FL 32611.

The Institute of Food and Agricultural Sciences (IFAS) is an Equal Opportunity Institution authorized to provide research, educational information and other services only to individuals and institutions that function with non-discrimination with respect to race, creed, color, religion, age, disability, sex, sexual orientation, marital status, national origin, political opinions or affiliations. U.S. Department of Agriculture, Cooperative Extension Service, University of Florida, IFAS, Florida A. \& M. University Cooperative Extension Program, and Boards of County Commissioners Cooperating. Larry Arrington, Dean 
plants (Figure 2). On average, T3 homes consisted of $65 \%$ landscape bedding that was irrigated with microirrigation; contrasting with $\mathrm{T} 1$ and $\mathrm{T} 2$ homes where typically less than $25 \%$ of the irrigated area was landscape bedding irrigated with sprinkler irrigation.

\section{Treatment 1}

Treatment one homes consisted of sprinkler irrigation systems and typical landscaping (Figure 1) where the homeowner controlled the irrigation scheduling. Typical landscaping implies a greater percent of turfgrass than bedding area. The homeowner interaction involved in treatment one homes could be considered as "set it and forget it", with minimal alteration of the irrigation schedule based on seasonal changes. The homes in T1 consumed the most water for irrigation purposes.

\section{Treatment 2}

Treatment two homes also maintained the existing irrigation systems and had landscapes which are mostly turfgrass, similar to T1 (Figure 1). The irrigation scheduling for T2 systems was updated monthly based on historical ET. The EDIS document "Operation of Residential Irrigation Controllers" (http://edis.ifas.ufl.edu/AE220) explains how to determine zone run times based on the irrigation zone water application rate. The document goes into detail on the suggested monthly zone run times based on historical ET. However, it is most important to adjust the irrigation run times based on seasonal weather changes. For the Central Florida Ridge area, depending on system performance and uniformity, the $\mathrm{T} 2$ run times were set according to Table 1

The homes in T2 consumed $16 \%$ less irrigation water than $\mathrm{T} 1$ based on monthly water use data over a 29-month period. Therefore, adjusting the controller setting seasonally can lead to a 640 to 800 gal savings per week based on typical system usage.

\section{Treatment 3}

Treatment three irrigation systems were designed according to specifications for optimal efficiency (i.e. Irrigation Association and Florida Irrigation Society)

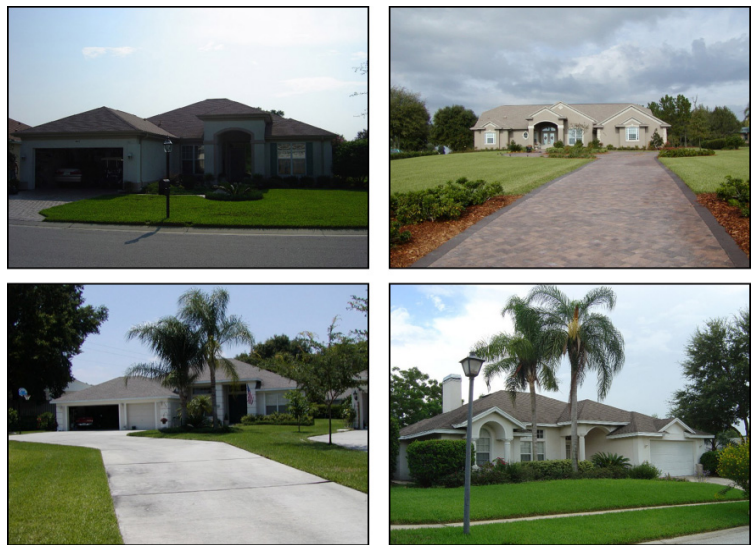

Figure 1. Examples of typical home landscapes, $\mathrm{T} 1$ and T2, where the turfgrass area is greater than the bedded area. Photo - Michael Dukes Credits: Photo - Michael Dukes

and include a landscape design that had minimal turfgrass and an increased use of native drought tolerant plants (Figure 2). To further achieve water savings in T3, most landscape plants were irrigated by microirrigation as opposed to standard spray and rotor heads. The average percentage of the irrigated area covered by turfgrass in $\mathrm{T} 1$ and $\mathrm{T} 2$ yards was $75 \%$, with the landscaped bedding accounting for the other $25 \%$ of the irrigated area. T3 yards had an average irrigated area of $35 \%$ turfgrass and $65 \%$ landscaped bedding. Some of the T3 yards had as little as $5-15 \%$ turfgrass.

Run time settings for $\mathrm{T} 3$ were the same as the $\mathrm{T} 2$ for the spray and rotor zones (Table 1). The run time settings for the T3 microirrigation zones typically followed the rotor zone settings. Once the ornamental plants are established, the microirrigation zone run times can often be decreased. In the winter months all microirrigation zones were greatly decreased or turned completely off.

The homes in T3 consumed 39\% less irrigation water than T1 (based on monthly water use data over a 29-month period), which would lead to a weekly water savings of 1440-1800 gal per week based on irrigating twice weekly for the homes included in this study.

\section{Seasonal water use}

Based on irrigation water consumption data collected over a 29-month period, the following seasonal water use averages were determined. 

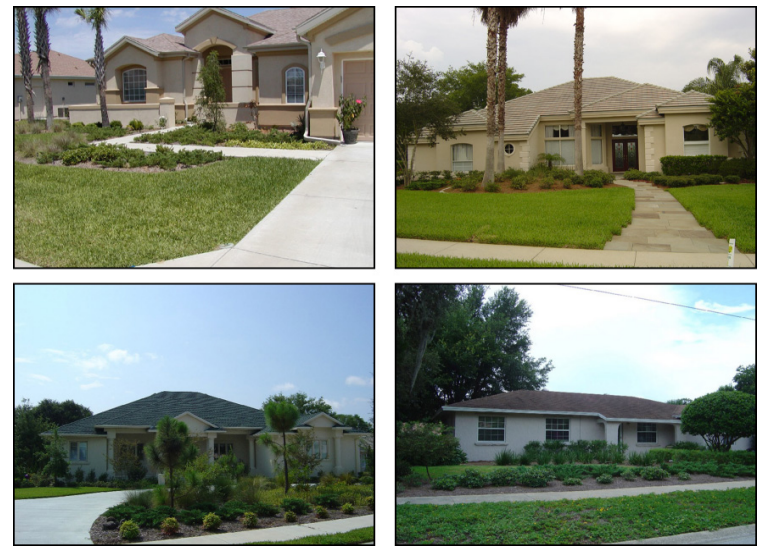

Figure 2. Examples of T3 landscapes, where the turfgrass area was minimized and the bedded area irrigated by microirrigation. Photo - Michael Dukes Credits: Photo Michael Dukes

Regardless of season, T1 systems used the most water for irrigation purposes (Table 2), whereas the T3 systems used the least water for irrigation purposes regardless of season. Irrigation water consumption was lowest in the winter months (December through February), as would be expected due to reduced plant needs.

Turfgrass quality ratings were based on the rating method of the National Turfgrass Evaluation Procedures, NTEP. This evaluation is based on visual estimates such as color, stand density, leaf texture, uniformity, disease, pests, weeds, thatch accumulation, drought stress, traffic, and quality. Turfgrass quality is a measure of aesthetics (i.e. density, uniformity, texture, smoothness, growth habit, and color) and functional use. The minimum rating while still maintaining acceptable quality is 6 , however lower ratings do not necessarily imply drought stress.

Treatments 1 and 2 maintained minimum or above average turfgrass quality during the entire data collection period of the project. The T2 turfgrass had no significant differences in quality from $\mathrm{T} 1$ turfgrass under decreased irrigation schedules.

The T3 lawns did have lower quality ratings compared to $\mathrm{T} 1$ and $\mathrm{T} 2$ for winter, summer and fall seasons. During these seasons the $\mathrm{T} 3$ ratings were just below 6 , the NTEP acceptable rating. The lower ratings for the T3 turf during the fall and winter months were because the turfgrass was permitted to go into partial dormancy. During dormancy, which is the normal state of turfgrass in the winter months, irrigation run times can be decreased as plants have decreased water needs. When the turfgrass goes into dormancy, the turfgrass color changes to tan rather than green. The decreased turf quality was color and not due to drought stress or winter injury. In the spring months, after "green-up", when the grass comes out of dormancy, the T3 turf quality was better than T1.

\section{Microirrigation in Landscape Bedding}

The T3 irrigation designs included microirrigation in the bedded areas. Microirrigation components used included micro-spray heads (Figure 3) and drip tubing (Figure 4). The benefit of microirrigation is the low volume water output, which allows for the irrigated area to be concentrated around the root zone. Thus, much of the bedded area did not receive irrigation water since it was the area in between plants. This reduced the effective irrigated area and saved irrigation water compared to sprinkler irrigation.

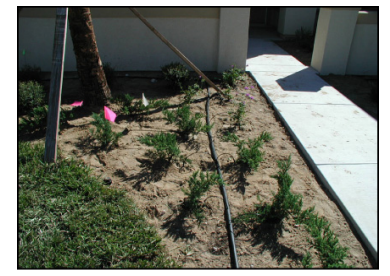

Figure 3. Microspray or microjets in a plant bed.Photo Michael Dukes Credits: Photo - Michael Dukes



Figure 4. Sample of drip tubing. Photo - Michael Dukes Credits: Photo - Michael Dukes.

\section{References}

Dukes, M.D. and D.Z. Haman. 2001. Operation of residential irrigation controllers. Circular 1421. Florida Cooperative Extension Service, Institute of Food and Agricultural Sciences, University of Florida, Gainesville, FL. 
Fernald, E., and E. Purdum. 1998. Water

Resource Atlas. Florida State University: Tallahassee, FL: Institute of Public Affairs.

Florida Irrigation Society. 1989. Standards and specifications for turf and landscape irrigation systems. $2^{\text {nd }}$ ed. Florida Irrigation Society, Inc., Winter Park, FL.

Irrigation Association. 2003. Turf and landscape irrigation best management practices DRAFT. Irrigation Association Water Management Committee, Falls Church, VA.

Marella, R.L. 1999. Water withdrawals, use, discharge, and trends in Florida, 1995. Water Resources Investigations Report 99-4002, U.S. Geological Survey, Denver, CO.

Shearman. R. C. and K. N. Morris. 1998. National Turfgrass Evaluation Procedure Workbook. NTEP Turfgrass Evaluation Workshop, October 17, 1998, Beltsville, Maryland.

USDC. 2001. U.S. Bureau of the Census, Population Estimates Program (PEP). Washington, DC.

Table 1. Seasonal irrigation run times for spray and rotor zones.

\begin{tabular}{|c|c|c|c|c|c|}
\hline \multirow{2}{*}{$\begin{array}{l}\text { Head } \\
\text { Type }\end{array}$} & \multirow[t]{2}{*}{ Setting } & \multicolumn{4}{|c|}{ Season } \\
\hline & & Summer & Fall & Winter & Spring \\
\hline \multirow[t]{2}{*}{ Spray } & Ideal & $25 \min$ & $\begin{array}{l}15 \\
\min \end{array}$ & $0 \mathrm{~min}$ & $\begin{array}{l}20 \\
\min \end{array}$ \\
\hline & Range & $\begin{array}{c}20-30 \\
\min \end{array}$ & $\begin{array}{c}10-20 \\
\min \end{array}$ & $\begin{array}{r}0-10 \\
\min \end{array}$ & $\begin{array}{c}15-20 \\
\min \end{array}$ \\
\hline \multirow[t]{2}{*}{ Rotor } & Ideal & $45 \mathrm{~min}$ & $\begin{array}{l}30 \\
\min \end{array}$ & $\begin{array}{l}<10 \\
\min \end{array}$ & $\begin{array}{l}40 \\
\min \end{array}$ \\
\hline & Range & $40-60 \mathrm{~min}$ & $\begin{array}{c}20-40 \\
\min \end{array}$ & $\begin{array}{c}0-20 \\
\min \end{array}$ & $\begin{array}{c}35-55 \\
\min \end{array}$ \\
\hline
\end{tabular}


Table 2. Seasonal water use and turf quality across treatments.

\begin{tabular}{|c|c|c|c|c|c|c|c|c|c|c|c|c|c|c|c|}
\hline & \multicolumn{3}{|c|}{ Winter } & \multicolumn{3}{|c|}{ Spring } & \multicolumn{3}{|c|}{ Summer } & \multicolumn{3}{|c|}{ Fall } & \multicolumn{3}{|c|}{ Average } \\
\hline & $\mathrm{T} 1$ & T2 & T3 & $\mathrm{T} 1$ & $\mathrm{~T} 2$ & T3 & $\mathrm{T} 1$ & $\mathrm{~T} 2$ & T3 & $\mathrm{T} 1$ & $\mathrm{~T} 2$ & T3 & $\mathrm{T} 1$ & T2 & T3 \\
\hline $\begin{array}{c}\text { Water } \\
\text { Use } \\
\left(\mathrm{gal} / \mathrm{ft}^{2}\right)\end{array}$ & 2.53 & 1.91 & 1.35 & 4.32 & 3.31 & 2.33 & 3.29 & 2.70 & 2.35 & 3.80 & 3.63 & 2.50 & 3.48 & 2.91 & 2.13 \\
\hline $\begin{array}{l}\text { Fraction } \\
\text { of Total } \\
\text { Water } \\
\text { Use (\%) }\end{array}$ & 75 & 63 & 37 & 77 & 74 & 42 & 82 & 66 & 63 & 62 & 61 & 55 & 75 & 66 & 46 \\
\hline $\begin{array}{c}\text { Turf } \\
\text { Quality } \\
\text { Rating }\end{array}$ & 5.7 & 6.4 & 5.4 & 5.9 & 6.6 & 6.4 & 5.8 & 5.6 & 5.1 & 6.6 & 6.9 & 5.8 & 6.0 & 6.3 & 5.7 \\
\hline
\end{tabular}

